\title{
A Discussion on the Organic Cohesion between College English Teaching and Bilingual Teaching
}

\author{
Yuxia Chen \\ Xijing Universiy, Xi'an City, Shaanxi Province, 710023, China
}

\begin{abstract}
The effective development of bilingual teaching helps students obtain the frontier professional knowledge, master the English terminology in the professional field and improve their English level. Besides, this will lay a solid foundation for their future participation in international exchanges. To improve bilingual teaching efficiency, we should start with the reform of college English teaching. Colleges can try the teaching model which relies on the teaching content and pay attention to cultivating students' English thinking ability. Based on the author's work and learning experience, this paper first analyzed the relationship between bilingual teaching and college English teaching, then proposed the cohesion problems between them. Finally, this paper put forward the cohesion strategies of college English teaching and bilingual teaching.

Keywords: College English; Bilingual teaching; Relationship; Cohesion strategies
\end{abstract}

\section{Introduction}

At present, students' English language level and teachers' teaching ability reflected in the bilingual teaching practice in most colleges and universities in China still cannot meet the requirements of bilingual teaching, which hinders the smooth development of the bilingual teaching. The main reason is that college English teaching and bilingual teaching are seriously out of touch in orientation, teaching content, teaching methods and learning strategies[1]. Students can not adapt to the sudden change from college English teaching which is to improve 
their English level to the bilingual teaching which takes English as a medium to impart professional content.

\section{The Relationship between Bilingual Teaching and College English Teaching}

College English teaching is a kind of teaching system which adopts diversified teaching methods to teach English under the guidance and support of English theory, including English language and culture, English application, English learning methods and international culture. Bilingual teaching can promote college English teaching. First of all, a good English learning environment is a basic condition for students to master the English knowledge. The dependence on classroom knowledge and extra-curricular exercises can not guarantee students' English proficiency. Bilingual teaching can ensure the completion of the teaching objectives in colleges and create a learning English condition for students to study anywhere and anytime. Bilingual teaching not only strengthens the study of specialized courses, but also promotes students' English proficiency. Secondly, bilingual teaching can improve college students' daily oral English ability and English comprehension ability[2]. Besides, it can cultivate international and interdisciplinary talents with comprehensive development, so as to lay a good foundation for China's international development.

\section{The Cohesion Problems between College English Teaching and Bilingual Teaching}

\subsection{Students' English proficiency is not compatible with bilingual teaching}

Most of the students can recognize the importance and necessity of bilingual teaching, and they look expectantly toward bilingual teaching. Besides, students approve of Bilingual teaching. It can not only promote English learning, but also arouse students' interest in professional learning to improve their overall quality, which has a positive meaning for the future development of students. However, in the implementation of bilingual teaching, many students' learning effect is not very satisfactory[3]. This is mainly because that students' English level, especially the listening level is not high. At present, college English teaching in China attaches more importance to the improvement of students' reading ability. Although the teaching goal of listening and speaking ability cultivation is relatively clear, the emphasis in practical teaching is not enough, which can not fully meet the needs of bilingual teaching. 


\subsection{The actual orientation of college English teaching does not meet the requirements of bilingual teaching}

The reform only rests on the curriculum reform in the basic stage and pays more attention to the reform of teaching model. Colleges fails to deepen the reform and ignores the improvement and reform of the course system and course content. The requirements of high school English teaching and college English teaching are obscure and even convergent. Besides, with the influence of CET, the focus of our teaching tends to rest on the basic language training, and some even remain in the examination - oriented teaching model. As the college English does not consciously connect teaching content, teaching methods, learning strategies and bilingual teaching together, the complementary relationship between the two has not been integrated in a real sense. Because of the influence of the orientation of college English teaching, students can not meet the requirements of bilingual teaching both in the English application ability and in the professional English level.

\subsection{The subject content learning and English ability improvement in Bilingual teaching fails to synchronize}

Students who study bilingual courses can acquire stronger application ability of the second foreign language than those students who study the second foreign language with the traditional teaching model. At the same time, students who study bilingual courses are not inferior to those students who only use the mother tongue to study all the courses, and their ability to use foreign language is obviously improved. In mathematics, sociology and other professional learning, the progress that the majority of students who study bilingual courses make shows that their professional competence is comparable to those who learn their courses with their mother tongue[4]. As the traditional language teaching focuses on language learning which does not pursue the content relevance and coherence and whose learning themes are not related, many students still fail to meet the requirements of bilingual teaching after two years of college English learning. Students often can not achieve goals of professional content learning and English ability improvement.

\section{The Cohesion Strategies of College English Teaching and Bilingual Teaching}

\subsection{To enhance teachers' teaching ability and change teaching methods}

Most teachers use English in classroom teaching and teaching activities are more colorful. In the bilingual classroom, it is still relatively common that teachers use Chinese or use Chinese and English interchangeably in teaching, and usually use the method that they speak an English sentence and then a Chinese sentence. 
Interaction between students or teachers and students is poor, so that it is difficult to stimulate students' interest in learning and there is a greater distance with the ideal bilingual teaching. College English teaching needs to change the traditional teaching model and adopt multimedia teaching model based on the computer and classroom to develop students' comprehensive English application ability. In addition to the reform of the teaching model, college English also should reform its teaching content[5]. Colleges can compress college English teaching hours in the basic stage and add English applied elective courses with different topics to fully develop students' English ability.

\subsection{To strengthen the teacher training and update bilingual teachers' knowledge structure}

Most of bilingual teachers are professional teachers in different departments of the school. Generally speaking, they are proficient in the major, but lack necessary English language teaching theory and solid basic language skills. They also lack necessary understanding of students' English level, which makes it very difficult for them to use English to teach the subject in an easy manner. In addition, there are a small number of compound professional teachers who learn English in undergraduate study and then learn other disciplines in their master's or doctoral study. These teachers are proficient in English and other majors. However, it is just a small number and is difficult to meet the bilingual teaching needs. In addition, the development of bilingual teaching also poses a challenge to college English teachers. In order to cultivate students' English ability and prepare language basis for the bilingual teaching, college English teachers not only should adapt to the needs of students and bilingual teaching in teaching methods and teaching models, but also should continue to learn and strive to make themselves compound English teachers by changing the pure language knowledge structure into the structure that combines language and other related professional knowledge.

\subsection{To adjust the curriculum and increase the proportion of professional English courses}

At present, bilingual teaching in China is difficult to achieve the desired goal. The reason is that the overall quality of teachers and English comprehensive application ability of students needs to be improved, especially the listening and speaking ability. Besides, there are many other reasons: students have a small vocabulary of professional English; they lack professional English syntax knowledge; their professional literature reading ability is poor; their professional communication skill in English is insufficient. To this end, the college English curriculum should increase the proportion of professional English courses, strengthen students' mastery of the language characteristics and cultivate students' professional literature reading proficiency and English listening and speaking ability in professional exchanges, so as to prepare for the bilingual teaching[6]. We should understand students' needs and their application of professional English by virtue of questionnaire, interview, observation, data collection and 
informal consultation and establish high-quality professional English courses that meet the needs of the society to pave the way for bilingual teaching.

\subsection{To establish specialized teaching management institutions to achieve the effective cohesion between college English teaching and bilingual teaching}

Bilingual teaching started late in China and professional teachers in the faculties are in charge of it. Generally, Teaching Affairs Offices are responsible for the coordination, rather than specialized teaching and research institutions, so that the management is in a relatively free state, which will undoubtedly affect the effective implementation of bilingual teaching. In order to improve the quality of bilingual teaching, the school can establish a specialized bilingual teaching and research management institution, which is responsible for the development of bilingual teaching plan in line with the actual situation of the subject, professional development and curriculum construction in colleges. It will promote the bilingual teaching in a planned and systematic way[7]. Besides, the institution should improve the quality of bilingual teaching in schools, promote the professional development of course teachers and provide evaluation systems for all bilingual courses. This will not only help solve problems in bilingual teaching, but also can make college English teaching more targeted and better for the bilingual teaching.

\subsection{To select teaching materials and pay attention to digestion and absorption}

Bilingual teaching advocates that teachers use foreign original and photoengraving materials. At present, China's bilingual teaching materials mainly include foreign original textbooks, photocopying materials, materials adapted from the original version and English-Chinese textbooks. As the foreign original and photoengraving versions are mature foreign teaching materials in the professional field, these are the best materials to develop bilingual teaching with the authentic language and systematic knowledge. The use of the original or photoengraving version of the textbook not only allows students to learn the frontier academic knowledge in foreign countries from a higher starting point, understand academic and technological developments and acquire pure professional language expression, but also contributes to teachers' mastery of foreign advanced teaching ideas, teaching methods and frontier professional information, so that our personnel training pattern will gradually connect with the international model.

\section{Conclusion}

The research on the cohesion between college English teaching and bilingual teaching is a complex systematic project, which requires the relevant departments and teachers to set up correct teaching ideas, actively participate in it and 
correctly handle the relationship between the two. Besides, it is necessary to promote the reform of college English teaching and improve bilingual teaching quality to enhance students' comprehensive English application ability and international communication competence in the professional field.

\section{References}

[1] Liu Pengjuan. An Analysis of the Cohesion Problems of College English Teaching and Bilingual Teaching. Chizi (On Trimonthly publication), (24), pp.91-92, 2014.

[2] Cui Xu'e. A Thinking on Status quo and Problems of the Cohesion between College English Teaching and Bilingual Teaching. Practical Electronicsx (13), pp.121-122, 2014.

[3] Yu Xiuhua. A Discussion on College English Teaching in China from the Perspective of Bilingual Teaching. Education and Vocation, (03), pp.113-114, 2014.

[4] Zhou En, Ding Nianqing. The Cohesion between College English Teaching and Bilingual Teaching: The Status quo and Thinking. Foreign Language World, (04), pp.68-75, 2012.

[5] Liu Daoying. An Analysis of the Cohesion between College English Teaching and Bilingual Teaching. Northwest Medical Education, 2011, (06): 1265-1267.

[6] Han Jinlong. EAP: College English Reform and Bilingual Teaching. Higher Education Exploration, (11), pp.24-25, 2007.

[7] JI Rongqin, Qian Shuqun. ESP Teaching - the Cohesion between College English and Bilingual Teaching. Journal of East China Jiaotong University, (11): 166-167, 2005. 